\title{
Land Use Guidelines to Maintain Habitat Diversity of Wood- Pastures in the Southern Carpathians Under Projected Climate Change
}

\begin{abstract}
The biodiversity of wood-pastures depends on a balance between human interference and natural vegetation succession, which however is undergoing changes driven by socio-economic factors and climate change. Widely spread throughout Europe, wood-pastures were subject to either intensification or abandonment, leading to habitat segregation and loss. This is currently the fate of large Romanian remnant woodpastures and climate warming further complicates management adaptation.

In a series of simulation experiments, we compared the long-term effects of different land use and climate change scenarios on the habitat diversity of a wood-pasture in the Southern Carpathians (Fundata village, Romania). We tested livestock densities according to management guidelines, complemented with shrub-cutting in order to maintain a structurally-diverse landscape with high habitat values in the light of climate change. We found that significant losses of open pastureland and inclusion into forest, as well as landscape structural simplification and loss of complex habitats can be expected from climate warming, with more severe consequences in a hotter climate perspective. We argue for the re-establishment of the traditional multi-use of wood-pastures at optimum livestock densities in combination with low-intensity shrubcutting, because our study demonstrated that traditional practices offer a balanced compromise between agricultural use and maintaining habitat mosaics that are robust to climate change.
\end{abstract}

\section{Keywords:}

wood-pastures, ecosystem modelling, nature conservation management, landscape structure, socio-economic change
Iona Stoicescu ${ }^{1 *}$, Ileana PătruStupariu I. ${ }^{2}$, Constantina-Alina Hossu $^{3}$, Alexander Peringer ${ }^{4}$

${ }^{1)}$ Research Institute of the University of Bucharest, ICUB; Transdisciplinary Research Centre LandscapeTerritory-Information Systems, CeLTIS, Romania

2) University of Bucharest, Faculty of Geography, Department of Regional Geography and Environment, Romania

${ }^{3)}$ University of Bucharest, Centre for Environmental Research and Impact Studies, Romania

${ }^{4)}$ Nuertingen-Geislingen University, Landscape Ecology and Resources Management, Germany

*Corresponding author: Ioana Stoicescu, Research Institute of the University of Bucharest, ICUB; Transdisciplinary Research Centre Landscape-TerritoryInformation Systems, CeLTIS, Splaiul Independentei nr. 91-95, 050095 Bucharest, Romania. Email: ioana. stoicescu@yahoo.com 


\section{Introduction}

In wood-pasture landscapes, grasslands, forests and interconnecting ecotones form a mosaic of habitats, with a high value for nature conservation (Bergmeier et al. 2010; Hartel et al. 2015). Widely spread throughout Europe, a process of segregation threatens these landscapes. Structurally-diverse mosaics with high habitat value shift either to (i) closed forest due to abandonment and subsequent forest succession, or (ii) almost treeless pastures due to intensification and subsequent cutting of isolated tree stands (Bergmeier et al. 2010; Chetelat et al. 2013; Fontana et al. 2014;Gallandat et al. 1995; Plieninger et al. 2015, 2003; Roellig et al. 2018; Vera 2000). In Romania, landscape simplification as a result of wood-pasture loss has recently gained intensity driven by socio-economic changes in the post-communism period(Hartel et al. 2013; Munteanu et al. 2014; Sutcliffe et al. 2015b, 2013). In Western Europe, this process led to significant losses of biodiversity over the past century (Brandt 2003; Hartel et al. 2015; Hartel \& Plieninger 2014; Makarewicz et al. 2012; Peringer et al. 2013; Plieninger et al. 2015; Roellig et al. 2018). Today, in the Carpathians, species which rely on the complex habitat structure of wood-pastures become threatened (Beaufoy et al. 2008; Bergmeier et al. 2010; Dorresteijn et al. 2013; Hartel et al. 2014; Hartel \& Plieninger 2014; Roellig et al. 2014). The loss of wood-pasture mosaics leads to a decrease in the ecological value of the entire landscape (Hartel \& Plieninger 2014; Marușca et al. 2014; Roellig et al. 2018, 2014; Sutcliffe et al. 2015b). In Romania wood-pastures are still widespread and now require ecologically-sound management strategies (Öllerer 2013; Palang et al. 2006). As wood-pastures origin from the traditional combination of multiple landuse forms, most prominently livestock grazing and tree and shrub-cutting for fire wood, sustainable economic strategies are required for the future to prevent their loss (Huber et al. 2013b; Plieninger et al. 2015; Sutcliffe et al. 2015b).

Wood-pasture landscapes found in the Southern Carpathians differ from those in Western Europe in that they were managed in a traditional manner in large areas until recent times, whereas traditional Western wood-pastures are often small and scattered relicts. Traditional grazing practices had been preserved in the Romanian Carpathian area. However today, socio-economic changes in the post-communist era led to the decline of the rural population, resulting in poor interest in pasture management and even abandonment (Baumann et al. 2011; Kuemmerle et al. 2009; Loos et al. 2016; Munteanu et al. 2014; Sutcliffe et al. 2013). Similar to many European countries, subsequent tree encroachment has profound implications for the legal state of pastureland. According to the Romanian Forest Code - Law no. 46/2008 (Parliament of Romania 2008), amended and supplemented by Law no. 175/2017 (Parliament of Romania 2017)Article 2 (paragraph b) and Annex 1 (definition 56, paragraph b), a wood-pasture has a tree cover of less than $40 \%$. In cases were under grazing leads to higher tree cover, the land becomes subject of forest inclusion and management (Romanian Forestry Code, Article 1, paragraph k) and semi-open habitats are lost. Climate change is accelerating tree encroachment even on pastures that are grazed by medium densities of livestock, because significantly of prolonged growing seasons in the mountains. Although certain minimum or maximum values have been proposed for Romanian wood-pasture management (APIA 2017; Marușca et al. 2014), former thin canopy tree stands tend to densify and can be expected to accelerate in the future(Peringer et al. 2016). The lack of pasture management also promotes tree encroachment, because shrub species such as juniper (Juniperus communis) facilitate tree regeneration by providing safe-sites against browsing (Smit et al. 2005). The cutting of shrub and young trees is therefore necessary not only for economic reasons as it was in the past, i.e. the maintenance of a large forage area with high forage quality. Today it appears to be a requirement to prevent wood-pastures from becoming subjected to the inclusion in the Forest Fund - and thus to be segregated from pastureland(Gordon \& Prins 2008).

Altogether, Romanian wood-pastures require adapted management strategies that cope with changing socio-economic and climatic factors and that raise the attractiveness of wood-pastures 
for agriculture again. However, both grazing intensification and tree and shrub-cutting must respect the wood-pasture's mosaic structure, as the high biodiversity is associated with structural diversity (Farina 2006; Hartel et al. 2015, 2014; Hilpold et al. 2018; Olff et al. 1999; Patru-Stupariu 2011; Roellig et al. 2014; Tucker \& Beaufoy 2014).

In order to investigate the combined effects of livestock grazing, shrub- and tree-cutting and climate change on vegetation succession and the emergence of habitats, we used the simulation model of woodpasture mosaic dynamics WoodPaM (Gillet 2008, Peringer et al. 2013, 2016, 2017). The model was developed to study these questions in the Swiss Jura Mountains (Gillet \& Peringer 2012; Peringer et al. 2013) and recently transferred to the Romanian Carpathians (Pătru-Stupariu et al. 2017; Peringer et al. 2016). WoodPaM is capable of simulating mosaic landscape dynamics for scenarios that combine these three factors of wood-pasture management (livestock density, tree and shrub-cutting, climate change). The results illustrate the effects of the spatial and temporal interactions among these factors on vegetation patterns that are interpreted in terms of habitat value for target species.

In our study we answer the following questions:

1. Are the currently proposed livestock densities for wood-pasture management sufficient to conserve the mosaic structure in the light of climate change?

2. Will tree and shrub-cutting additional to grazing help to mitigate forest-grassland segregation or will pasture clearing promote structural simplification and the loss of ecotones?

3. May shifts in the structure of wood-pasture mosaics driven by long-term climate change be counteracted by adapted livestock densities and tree and shrub-cutting practices?

Altogether, we aim to provide arguments in the formulation of sustainable management guidelines towards the maintenance of a balance between the main functions of a wood-pasture landscapes, i.e. forage, wood and habitat provision.

\section{Methods}

In the following sections, we present the study area, the interviews on past and current land management practices, the topographic data used for model initialization and the land use and climate change scenarios used for simulations. Fig. 1 shows how data was combined to scenarios and how model output is evaluated.

\subsection{Study Areas}

Our study area is located in the commune of Fundata (Brașov County, Romania), in the central part of the Bran Passageway crossing the Southern Carpathians (Fig. 2).

The commune of Fundata is situated at $1250-1360$ $\mathrm{m}$ a.s.l. Its mountain climate is described by an average yearly temperature of $4-6^{\circ} \mathrm{C}$ and $800-1000$ $\mathrm{mm}$ of yearly precipitation (Bîrsan and Dumitrescu 2014; Pepene \& Popovici 2012). The rolling relief is covered by deep, partly acid soils in alternation with limestone rock outcrops. Forests outside the woodpastures are dominated by European beech (Fagus sylvatica Linn.), whereas inside pastures Norway spruce (Picea abies Linn.) and juniper (Juniperus communis) constitute the grassland-forest ecotones and offer safe-sites for beech-establishment (Doniță et al. 2005; Dovčiak et al. 2007; Olff et al. 1999). Fertile pastureland was private even during the communist regime and these properties are fenced and located in the valleys and at the foothills. To the contrary, the hilltop area was part of the commonage land during the communist regime and a large part of it is now extensively used or abandoned (see Appendix 1). It is these commonage pastures, where forest-grassland mosaics are structurally rich and habitat diversity is further enhanced by shallow soils and rock outcrops (Pătru-Stupariu et al. 2017). Continuous land use in Fundata started around 1650 $A D$ with the establishing of permanent settlements (Pepene \& Popovici 2012).

The model landscape is a wood-pasture located in the south-western area of Fundata (45.430884 lat. N, 25.260427 long. E, Fig. 3). Old beech forest forms the outer edge of the pasture (Pătru-Stupariu et al. 2011).The pasture itself was recently colonized by spruce and juniper (Fig. 4). 


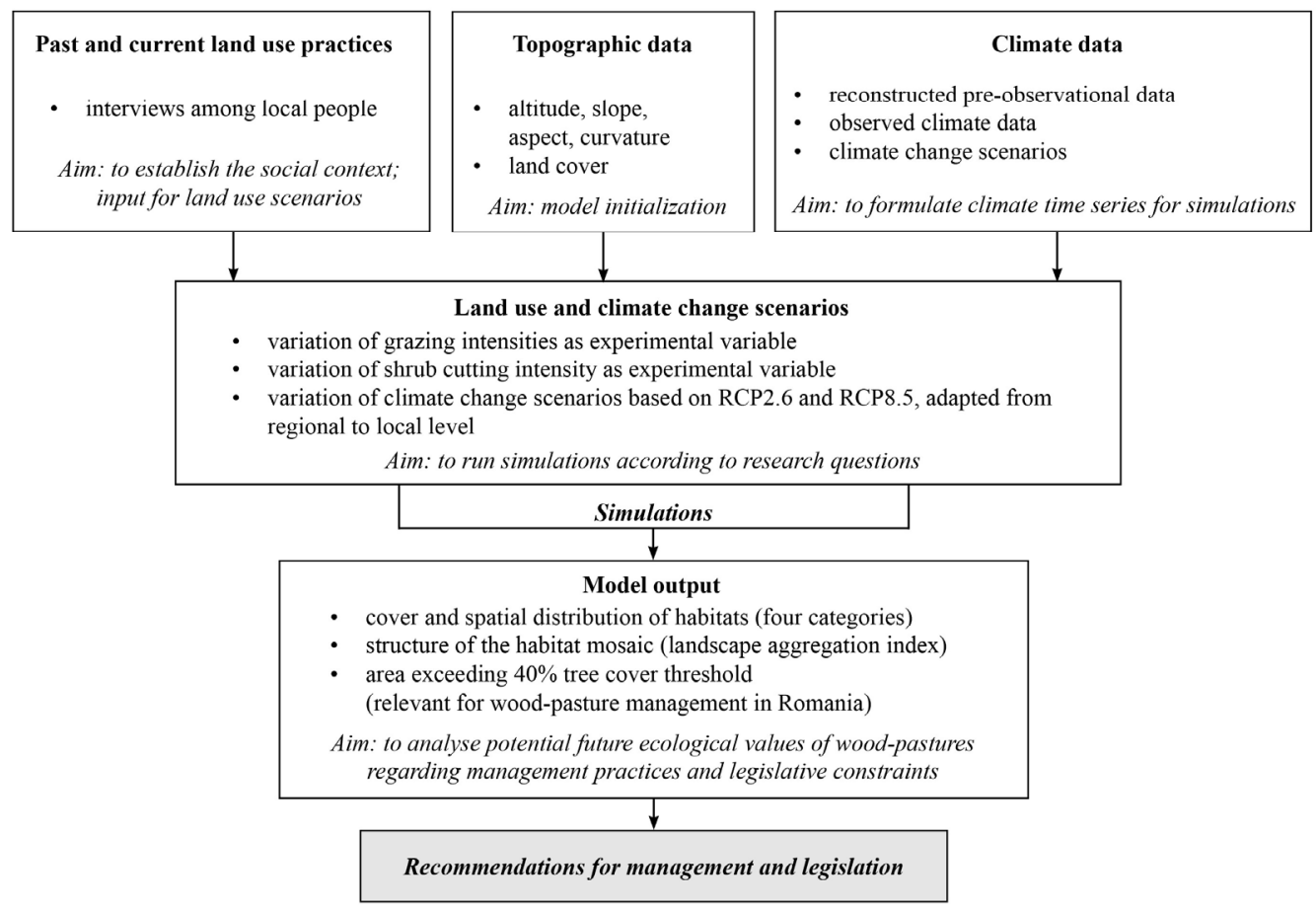

Figure 1 : Flow chart of the study design. Land use information from interviews among local people is combined with topographic data and climate change time series for scenario formulation. Simulation experiments test alternative landscape developments. Model output is analysed regarding nature conservation value and management options.
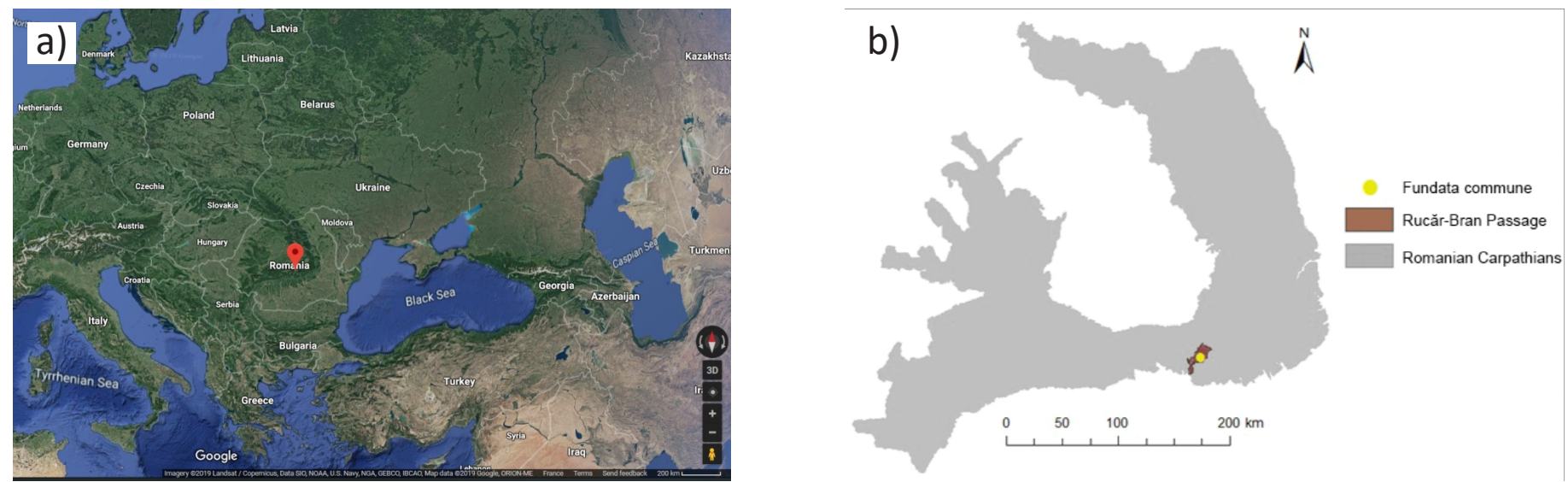

Figure 2: Location of the study area: a) location of Fundata commune in Romania, Europe (Google Maps view); https:// goo.gl/maps/VwFUcwANSgu85e9SA, Within the yellow outline: the Romanian Carpathians (extent of zoom in fig. b).

b) location of Fundata commune, Brașov County, Rucăr-Bran Passage) in the bow of the Romanian Carpathians

a) August 1977, aerial image Source: US Geological Survey

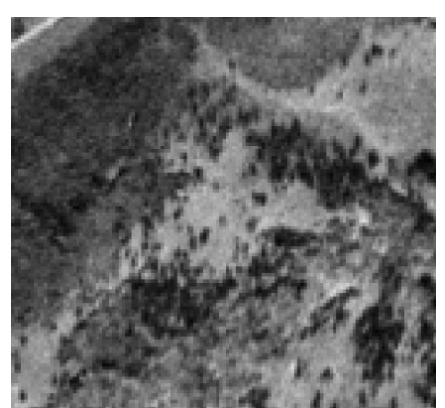

b) August 2013, aerial image Source: Wind Land project

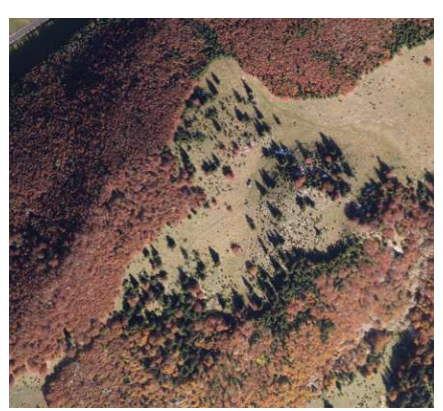

c) 2018 , satellite image Source: CNES/ Google Maps

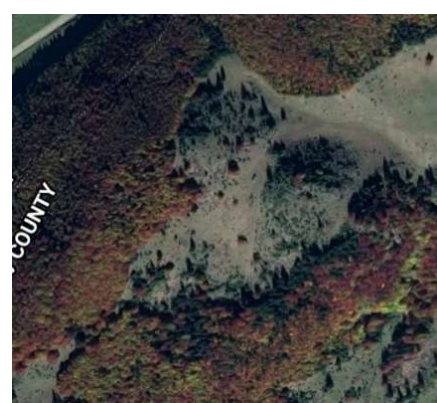

Figure 3: Aerial view of the study area. Widespread encroachment of juniper and spruce is dominant between years 2013 and 2018 on steep slopes with rock outcrops, whereas plains with deep soils in the centre of the pasture remain almost treeless (topographic maps are shown in the Supplementary Material, Appendices 1 to 3). 
Some of the juniper and spruce individuals already exceed two meters in height (Fig. 5) and increasingly shade the herb layer dominated by Nardus stricta. The pasture is a small part of the commonage area free of fences so that livestock may freely roam without further shepherding. Grazing is of low intensity and non-systematic (Marușca et al. 2014) and there is a lack in maintenance measures (such as shrub clearing). The pasture well represents the general trend of shrub and tree encroachment of wood-pastures in the area.

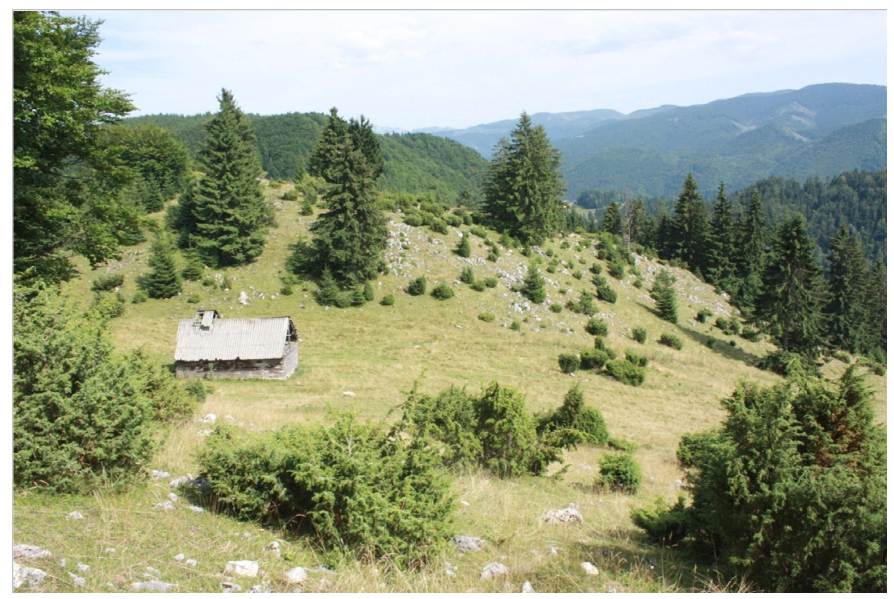

Figure 4: Image from the model landscape (the eastern area of the pasture). August 2014. Limestone rock outcrops; pasture colonization is performed by spruce (P. abies); another abundant key species: juniper (J. communis).

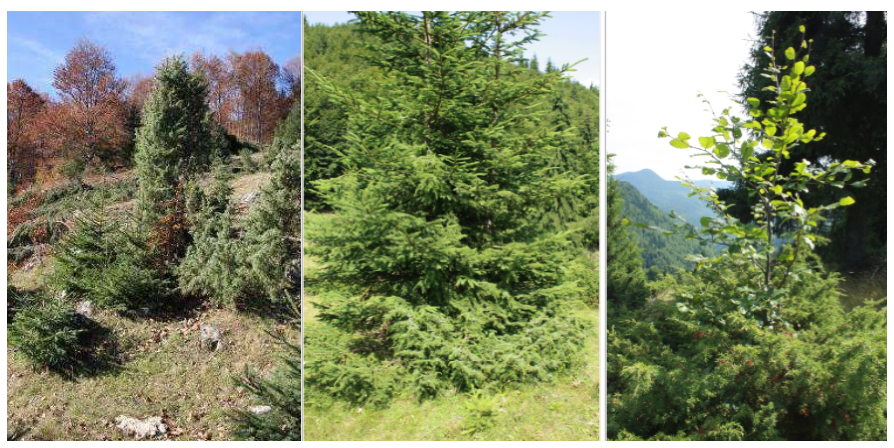

Figure 5: Images from the model landscape, Fundata village, Brașov County. August 2014. Dominant woody plant species: beech in the pasture surroundings; spruce and juniper in the pasture itself. Inside juniper shrubs, even beech is about to establish (safe sites in nurse shrubs; Olff et al. 1999; Olff \& Ritchie 1998; Peringer et al. 2015; Vera 2000).

\subsection{Interviews on past and current land use practices}

In order to collect information on past and current pasture management and grazing activities, semistructured interviews were conducted among
Fundata villagers $(\mathrm{N}=20)$. Local people were selected through a snowball sampling technique strategy (Flynn 1973) combined with random sampling. The snowball sampling strategy was applied to capture the main group of individuals that are informed about the grazing practices, their extent and intensity. The random sampling was selected to fully cover all the age classes (except for citizens younger than 18 years old), gender and various professions (Tab. 1).

Table 1: Interviewees' characteristics

\begin{tabular}{lc} 
Profession & $\begin{array}{c}\text { Number of } \\
\text { interviews }\end{array}$ \\
\hline Farming & 7 \\
\hline Education & 2 \\
\hline Health & 2 \\
\hline Commercial & 2 \\
\hline Technical & 2 \\
\hline Retired & 5 \\
\hline Gender & 12 \\
\hline Male & 8 \\
\hline Female & 5 \\
\hline Age group & 5 \\
\hline $19-35$ years old & 7 \\
\hline $36-50$ years old & 3 \\
\hline $51-60$ years old & \\
\hline Over 65 years old & \\
\hline
\end{tabular}

Interviews with local people were conducted in the local language, in different locations, including the Fundatatown hall, public spaces within the village or citizens' homes. The interview was structured into the following sections: (i) local people's knowledge about past and current land management practices with a focus on grazing pressure, (ii) local people's perception about signs of land use intensification or abandonment and (iii) interviewees' profile (gender, age and profession). The questions were asked in a direct manner (face-to-face) and adapted to targetgroup typology (using different words for the same content e.g. for the young and the old). The answers of the interviewees were transcribed during the interview sessions by an assistant and the length of the interviews varied between 30 and 40 minutes. 
The interviews were subject to content analysis. We used the results to form a general perspective regarding land management (refer to the results section 3.1), which was the basis for the formulation of land use scenarios for simulations (section 2.6).

\subsection{The WoodPaM model}

WoodPaM is a spatially explicit deterministic model, able to simulate vegetation dynamics in mountain wood-pastures (Gillet 2008; Peringer et al. 2016, 2013). It is a grid-based model (square cell size is $25 \mathrm{~m} \times 25 \mathrm{~m}$ ) that operates at a yearly time step. At cell level, WoodPaM simulates the succession of herb-layer communities and the dispersal, establishment and growth of woody vegetation that are both influenced by grazing and browsing impacts of livestock and climate (elevation above sea level, continentality, slope exposition). At landscape level, WoodPaM simulates the dispersal of tree species (in neighbouring cells, as well as long-distance) and selective habitat use of livestock. Habitat selectivity considers herbaceous forage availability, tree cover and steepness of slopes. Thereby, a feedback loop is established in the model between the grazing and browsing impacts on vegetation at cell level and the tree cover distribution at landscape-scale. The feedback is further conditioned by the topography and the meso-climate. Based on this hierarchical and process-based structure, WoodPaM mimics the emergence of forest-grassland mosaics following livestock-vegetation-climate interactions. A detailed model description is given in Gillet (2008) and Peringer et al. (2016, 2013). In our study, we used the same model version as applied in Peringer et al. (2016), in which the model was transferred from the Swiss Jura Mountains and calibrated to our study site in the Romanian Carpathians.

\subsection{Topographic data used as model input}

In order to initialize the WoodPaM model, the following topographic data was used (details are given in the Appendices 2 and 3 in the Supplementary Material):

- altitude (digital elevation model 1:25 000, from LiDAR data),

- slope, aspect and curvature computed from the digital elevation model.
The model landscape covers the pasture area shown in Fig. 1.3 and consists of 841 grid cells $(25 \times 25 \mathrm{~m} 2)$. Hills and valleys as well as slopes and plains are well expressed. Rock outcrops were estimated from the combination of terrain slope and curvature based on the method used in the Swiss Jura Mountains (rock is exposed on convex surface and increasingly with steepness; Peringer et al. 2013) and fit the observed pattern well (Fig. 3 and 4). The model landscape therefore well represents the terrain characteristics of commonage pastures in the area. Its size is large enough to allow for the simulation of self-organization processes in vegetation pattern formation. On the other hand, the area is small enough to clearly demonstrate mosaic pattern shifts following the scenarios.

\subsection{Climate time series}

The climate data used for the simulations, namely the mean monthly temperature and monthly precipitation sum, is divided into three categories:

i) for the pre-observations period (1-1961 AD), stochastic climate was compiled based on reconstructions of annual temperature fluctuations (data source: Moberg et al. 2005). Seasonal variability was generated stochastically based on the standard deviations of the observed data. This early period was important for the model spin-up (refer to section 2.6). Fig. 6 displays the pre-observational period between years 1650 and 1960 (termed PRE-OBS).

ii) for 1961-2016 AD observations were at hand from the Fundata Meteorology Station (1376 masl) (Fig. 6, termed OBS), provided by the National Meteorology Agency from the ROCADA dataset (Bîrsan \& Dumitrescu 2014);

iii) for 2017 to 2099 AD, two climate change scenarios were adapted from regional to local level based on the IPCC scenarios RCP2.6 and RCP8.5, using the EUROCORDEX dataset (Bojariu et al. 2015; Jacob et al. 2014) provided by the Romanian National Meteorology Agency. Fig. 6 shows the "cool" scenario CLIM2.6 (temperatures in orange and precipitation in medium-dark blue) and the "hot" scenario CLIM8.5 (temperatures in dark orange and precipitation in dark blue). 


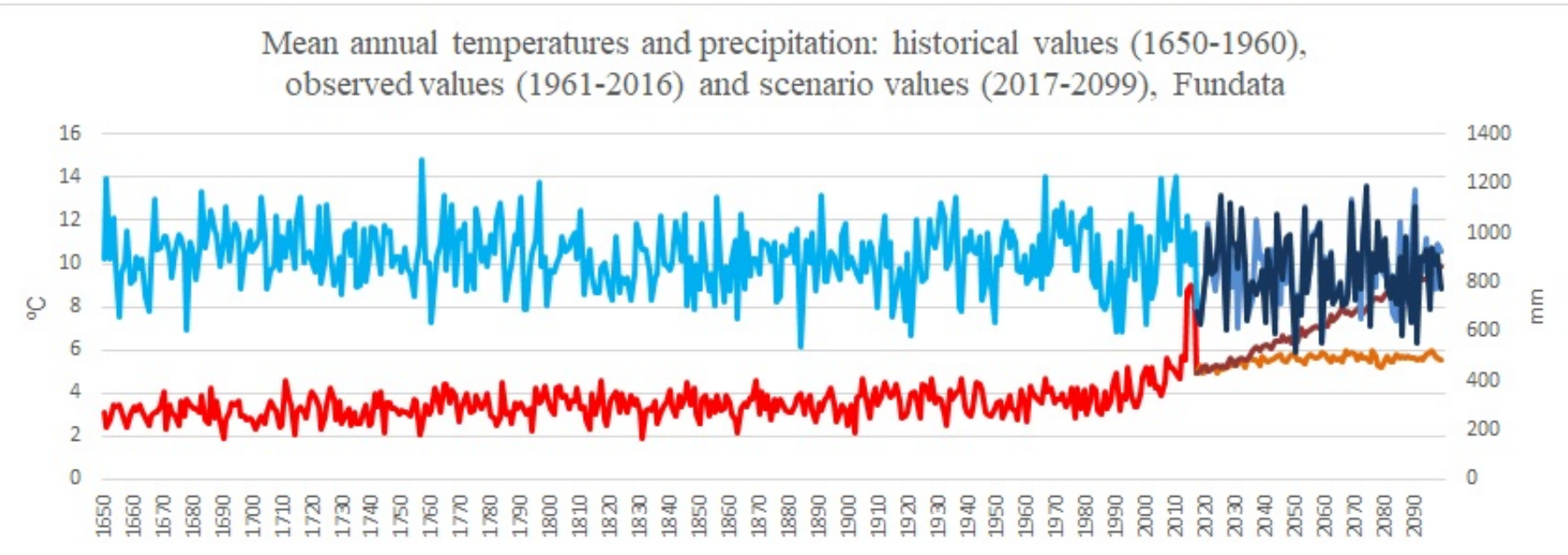

Calendar years

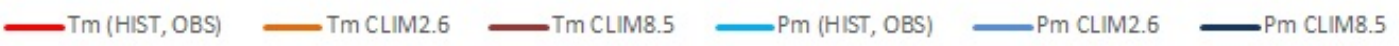

Figure 6: Climate time series for simulations shown as yearly average temperatures (red/orange shades) and precipitation sum (blue shades). It is composed of: part of the pre-observation period used for model spin-up (PREOBS, 1650-1960), observed values (OBS, 1961-2016) and climate change scenarios based on RCP2.6 (CLIM2.6) and RCP8.5 (CLIM8.5), adapted from regional to local level.

\subsection{Design of simulation experiments: land use and climate change scenarios}

All simulations started with a model spin-up period without grazing (years 1-1650 AD), which allowed for the development of a mixed forest community consisting of beech and spruce (tree species that are present in the landscape today). Cattle grazing started in calendar year 1650 AD (Pepene \& Popovici 2012) with livestock densities that gradually varied in between 0.3 and 0.7 adult bovine units per hectare $\left(A B U h^{-1}\right)$ with steps of $0.1 \mathrm{ABU} \mathrm{ha}^{-1}$ (grazing scenarios). Throughout the simulation interval (1650-2099 AD), the grazing intensity was maintained constant for each scenario and grazing duration was 120 days per year (short growing period of mountain climate). The cattle forage consumption was also held constant at current level. Therefore, we did not account for fluctuations in historic landuse and less productive breeds in the past. These shortcomings were disregarded, because we aimed to test the future consequences of current practices. Grazing pressure was estimated in $\mathrm{ABU} \mathrm{ha}^{-1}$ (adult bovine units per hectare) according to the definition provided by the Romanian Guide for Pastoral Management: "An adult bovine unit represents the load or the livestock for one hectare of pastureland and is established according to the green forage production per hectare, as well as the green forage needs of an animal for one day or for a certain amount of time." (Marușca et al. 2014). Depending on the livestock types foraging in the pasture (cattle of different ages, sheep etc.), the conversion into $A B U$ can be made according to the methodology provided by the Romanian legislation (MADR 2013).

The variation of livestock densities aims to test the consequences of future under-use of the pastures, as it was indicated by the interview results (refer to section 3.1), and of future intensification (in case subsidies raise interest again, section 3.1). The values cover the range in between the minimum and the maximum grazing pressure according to Romanian official documents and legislation in the field of pasture management:

- $0.3 \mathrm{ABU} \mathrm{ha}^{-1}$ is the minimum permitted stock density for permanent pastures, according to Article 7(1) of the Ordinance no. 544/2013 regarding the methodology to calculate pasture optimum stock density, issued by the Romanian Ministry of Agriculture and Rural Development 
(MADR 2013). Moreover, this minimum threshold is one of the conditions under which a pasture can be considered eligible for European subsidies, according to the Emergency Ordinance no. 34/2013 (Government of Romania 2013), art. 9, par. 6. This value is also part of official documents issued by Romanian authorities, such as The Informative Guide for Beneficiaries of the Environment and Climate Measures of the National Rural Development Program 20142020 (APIA 2017)and The Farmer's Guide on Ecoconditionality in 2017, issued by the Romanian Ministry of Agriculture and Rural Development (MADR 2017).

- $0.5 \mathrm{ABU} \mathrm{ha}^{-1}$ is the (current) optimum livestock density suggested by ty (Maruşca, personal communication in November 2014).

- $0.7 \mathrm{ABUha}^{-1}$ is proposed as the maximum grazing pressure (APIA, 2017) for grasslands of high importance for bird species (Crex crex) and butterfly species (Maculinea sp.).

For shrub-cutting, two scenarios were defined that represent active pasture clearing for maintenance and no additional pasture management apart from grazing. The variation of shrub-cutting aims to test the consequences of the future (re-)establishment of pasture management (supported by subsidies) or the disregard, as it was indicated by the interview results (refer to section 3.1). Shrub-cutting frequency was yearly as recommended in the Romanian farmers' guide for pasture management (Marușca et al. 2014). Extent of shrub-cutting was $50 \%$ of the model landscape with randomly selected grid cells. Thereby, in the neighbourhood of managed grid cells, a certain cover of shrubs is respected as favourable for biodiversity conservation and in irregular distribution (Gallé et al. 2017; Nikolov et al. 2011). Thereby, landscape structural simplification by large clear-cut areas is avoided. Shrub and tree cutting was introduced starting in year 2020, in order to test if pasture cleaning practices help mitigate forest-grassland segregation in the context of climate change scenarios. The intensity of pasture cleaning was maintained constant from year 2020 until 2099.

Each grazing scenario was tested in combination with each shrub-cutting scenario and with the two climate change scenarios, which lead to a total number of 20 scenarios simulated with WoodPaM (Tab. 2).

\subsection{Analysis of model output}

For each scenario, we analysed the structural complexity of the simulated landscapes, using the landscape aggregation index AIL (He et al. 2000), which distinguishes disperse vs. compact distributions of habitat types (Gallandat et al. 1995, Legend table of Appendix 4). A low value of the AIL corresponds to disperse habitat mosaics, while a

Table 2: Definition of scenarios: 5 grazing pressures $(\mathrm{Gr})$ are combined with two shrub-cutting scenarios

(SC y/n) and two climate change scenarios (CLIM).

\begin{tabular}{|c|c|c|c|c|c|c|c|}
\hline \multicolumn{8}{|c|}{ Definition of scenarios } \\
\hline \multicolumn{2}{|c|}{ Livestock density } & & $\begin{array}{c}\text { Gr0.3 } \\
\left(0.3 \mathrm{ABU} \mathrm{ha}^{-1}\right)\end{array}$ & $\begin{array}{c}\text { Gr0.4 } \\
\left(0.4 \mathrm{ABU} \mathrm{ha}^{-1}\right)\end{array}$ & $\begin{array}{c}\text { Gr0.5 } \\
\left(0.5 \mathrm{ABU}^{-1}\right)^{-1}\end{array}$ & $\begin{array}{c}\text { Gr0.6 } \\
\left(0.6 \mathrm{ABU} \mathrm{ha}^{-1}\right)\end{array}$ & $\begin{array}{c}\text { Gr0.7 } \\
\left(0.7 \mathrm{ABU} \mathrm{ha}^{-1}\right)\end{array}$ \\
\hline \multicolumn{8}{|c|}{ Scenario } \\
\hline \multirow{2}{*}{$\begin{array}{l}\text { Climate } \\
\text { change: } \\
\text { CLIM2.6 }\end{array}$} & $\begin{array}{l}\text { Shrub- } \\
\text { cutting } \\
\text { (SC) }\end{array}$ & $\mathbf{n}$ & $\begin{array}{c}\text { Gr0.3-CLIM2.6, } \\
\text { noSC }\end{array}$ & $\begin{array}{c}\text { Gr0.4- CLIM2.6 } \\
\text { noSC }\end{array}$ & $\begin{array}{c}\text { Gr0.5- CLIM2.6, } \\
\text { noSC }\end{array}$ & $\begin{array}{c}\text { Gr0.6- CLIM2.6 } \\
\text { nosC }\end{array}$ & $\begin{array}{c}\text { Gr0.7- CLIM2.6 } \\
\operatorname{noSC}\end{array}$ \\
\hline & $\begin{array}{l}\text { Active } \\
\text { no/yes }\end{array}$ & y & $\begin{array}{c}\text { Gr0.3- CLIM2.6, } \\
\text { SC }\end{array}$ & $\begin{array}{c}\text { Gr0.4- CLIM2.6, } \\
\text { SC }\end{array}$ & $\begin{array}{c}\text { Gr0.5- CLIM2.6, } \\
\text { SC }\end{array}$ & $\begin{array}{c}\text { Gr0.6- CLIM2.6, } \\
\text { SC }\end{array}$ & $\begin{array}{c}\text { Gr0.7- CLIM2.6, } \\
\text { SC }\end{array}$ \\
\hline \multirow{2}{*}{$\begin{array}{l}\text { Climate } \\
\text { change: } \\
\text { CLIM8.5 }\end{array}$} & $\begin{array}{l}\text { Shrub- } \\
\text { cutting } \\
\text { (SC) }\end{array}$ & $\mathbf{n}$ & $\begin{array}{c}\text { Gr0.3- CLIM8.5, } \\
\text { noSC }\end{array}$ & $\begin{array}{c}\text { Gr0.4- CLIM8.5, } \\
\text { noSC }\end{array}$ & $\begin{array}{c}\text { Gr0.5- CLIM8.5, } \\
\text { noSC }\end{array}$ & $\begin{array}{c}\text { Gr0.6- CLIM8.5, } \\
\text { noSC }\end{array}$ & $\begin{array}{c}\text { Gr0.7- CLIM8.5 } \\
\text { noSC }\end{array}$ \\
\hline & $\begin{array}{l}\text { Active } \\
\text { no/yes }\end{array}$ & y & $\begin{array}{c}\text { Gr0.3- CLIM8.5, } \\
\text { SC }\end{array}$ & $\begin{array}{c}\text { Gr0.4- CLIM8.5, } \\
\text { SC }\end{array}$ & $\begin{array}{c}\text { Gr0.5- CLIM8.5, } \\
\text { SC }\end{array}$ & $\begin{array}{c}\text { Gr0.6- CLIM8.5, } \\
\text { SC }\end{array}$ & $\begin{array}{c}\text { Gr0.7- CLIM8.5, } \\
\text { SC }\end{array}$ \\
\hline
\end{tabular}


high value indicates mosaic pattern segregation. The Romanian Forest Code defines wood-pastures with a tree cover of less than $40 \%$ (Parliament of Romania 2008). In order to illustrate how vegetation dynamics influences land management options, we calculated the area where tree cover was simulated to exceed $40 \%$ and where, subsequently, land would risk the inclusion into the National Forest Fund (hence the exclusion from the pastoral management, leading to mosaic landscape segregation).

We compared the results for three analytical time steps, namely years 2013, 2050 and 2099. 2013 corresponds to the most recent aerial image of the pasture (Fig. 3) within the observed climate time series, 2050 to near and 2099 to far climate change (diagrams in Fig. 7).

\section{Results}

\subsection{Interview results}

$70 \%$ of the answers suggest that landscape changes in the past years have been caused mainly by socioeconomic factors. In the communist regime, Fundata villagers have been using a large commonage pastureland. After recent shifts in land ownership, most of the commonage area has become private and underused. Regarding management practices, all of the interviewees view the wood-pasture as poorly managed and point out that shrub clearing is highly neglected.

$20 \%$ of them consider this to be caused by the migration of the young population towards urban areas, while $15 \%$ point out the misuse of subsidies received for pasture management. $95 \%$ of the locals point out intensive clear-cuts in the neighbouring forests and therefore economic interest in forestry instead of grazing and shrub-cutting.

Based on these results, we integrated two points into the design of land-use scenarios: (i) Current underuse and poor management is modelled by scenarios with low grazing pressure and absence of shrub-cutting. (ii) Appropriate use of subsidies might shift the economic interest from forest back to the pastures, which is modelled by scenarios with high grazing pressure and active shrub-clearing. For the scenario design refer to section 2.6.

\subsection{Simulation results}

The simulation results are shown in terms of the gradient analysis for varying livestock densities. Fig. 7 shows our key landscape state variables, i.e. the total area in which tree cover exceeds $40 \%$ (EX40\%, black) and the landscape aggregation index (AIL, grey) in order to indicate landscape structural diversity. Both are plotted against the simulated grazing pressures with and without shrub cutting and for both climate change scenarios.

This aggregated form of model output is complemented in Appendices 4 and 5 with maps of simulated habitat mosaics for all scenarios. Here we also show maps of the potential future loss of woodpasture area by forest inclusion, illustrating for each simulated landscape the areas where tree cover exceeds $40 \%$.

\subsubsection{Results for recent climate}

The model output for year 2013 AD (first row in Fig. 7) well reproduced the recommendations of Marușca (2014) for pasture management based on the experience of the past. Namely optimum grazing pressure (0.5 ABU ha-1 in Fig. 7) maintained the entire pastureland at its highest landscape structural diversity (AIL, grey line, was lowest) and tree cover was below $40 \%$ (black line) in the entire landscape.

Also the recommended minimum livestock density (0.3 ABU ha-1) kept almost two thirds of the pasture area in a semi-open state, but one third presented the risk of forest inclusion. Structural diversity was simpler due to widespread tree and shrub encroachment and lack of true open pasture (Appendix 4). The maximum livestock density (0.7 $A B U$ ha $^{-1}$ ) led to almost treeless pasture (Appendix 4 ) and subsequent simpler landscape structure.

\subsubsection{Results for climate change scenarios in the} absence of shrub-cutting

For the future, the model suggests that the relation among grazing pressure, open pastureland and landscape structural diversity remarkably depends on hot vs. cool climate change perspectives (diagrams for near and far climate change in rows 2 and 3 in Fig. 7). In the absence of shrub-cutting (solid lines), areas with more than $40 \%$ tree cover increased with climate warming and the increase was stronger in 


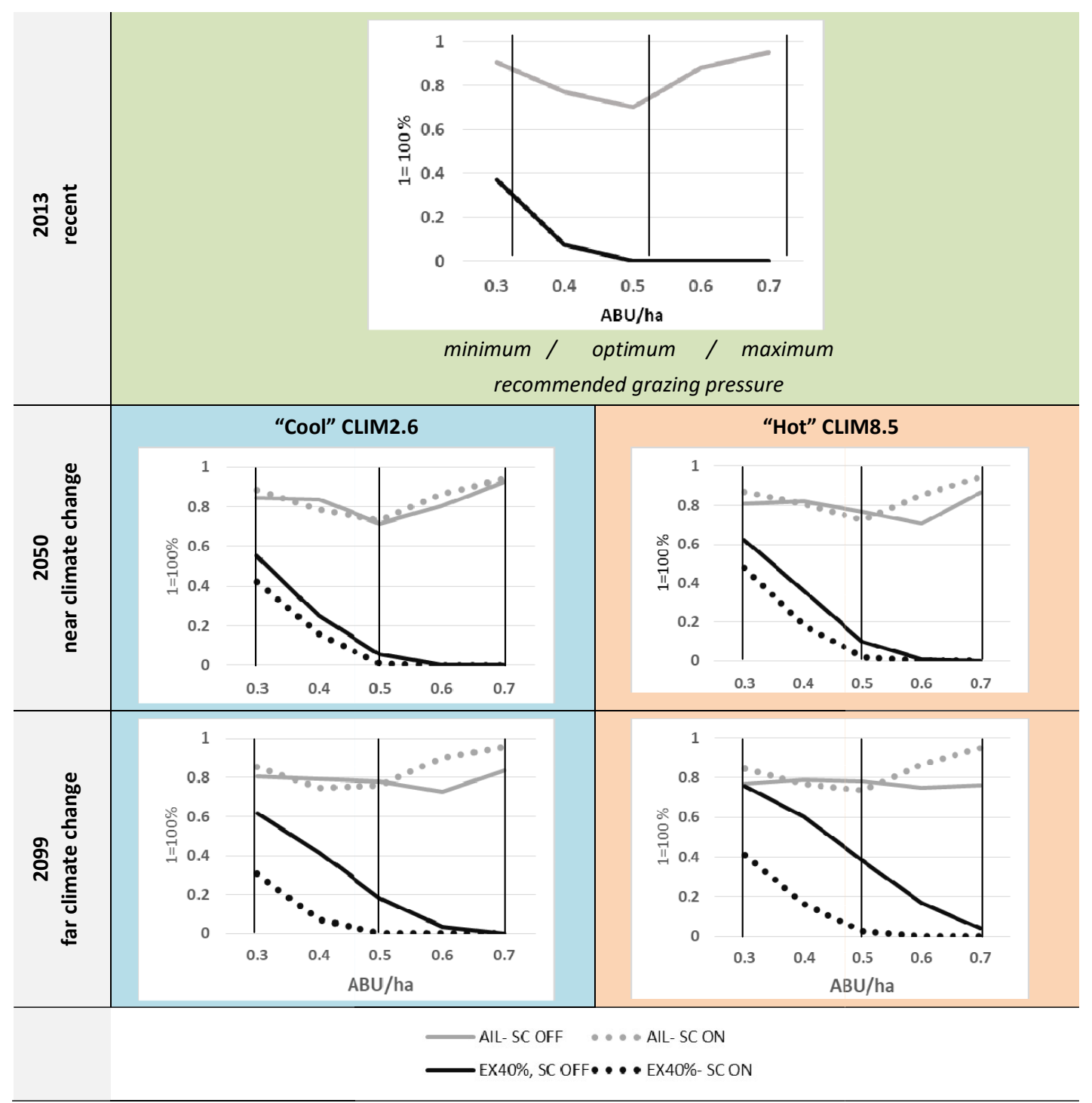

Figure 7: Variation of landscape properties (lines) along the gradient in grazing pressure (X-axis) for the two climate change scenarios (columns) at the analytical time steps 2013, 2050 and 2099 AD (rows). The lines indicate the landscape structural diversity (AIL) in grey and the percentage of the pasture area where tree cover exceeds $40 \%$ in black. Continuous lines indicate scenarios, which do not include shrub-cutting (SC OFF); dotted lines indicate scenarios, which include shrub-cutting (SC ON). The climate change scenarios are separated in columns (CLIM2.6 left side, CLIM8.5 right side).

hotter climate (black lines generally rose to higher values). Regarding historic optimum grazing (0.5 $\mathrm{ABU} \mathrm{ha}^{-1}$ ), the potential loss of open pastureland by forest inclusion was double for hotter than for cooler climate change (compare values for area with $40 \%$ tree cover at $0.5 \mathrm{ABU}^{\text {ha-1 }}$ among climate change scenarios at time steps 2050 and 2099 AD). Regarding minimum grazing $\left(0.3 \mathrm{ABU} \mathrm{ha}^{-1}\right)$, the trend was similar: the area with tree cover exceeding 40 $\%$ almost doubled after far future climate warming, but the differences among cooler and hotter climate were less pronounced. Maximum grazing (0.7 ABU $\mathrm{ha}^{-1}$ ) always maintained open pastureland. The other way round, the maintenance of similar proportions of open pastureland required an increase of livestock densities of about $0.1 \mathrm{ABU}$ ha-1 in the near future (2050 AD) and $0.2 \mathrm{ABU} \mathrm{ha}^{-1}$ in the far future (2099 $A D$, note the shift of the black solid lines towards right hand side).

It appeared that, in general, the optimum landscape structural diversity (grey solid lines)also shifted towards higher grazing pressures with climate warming (the location of lowest AlL shifted to the right along the grazing pressure gradient). This process was accelerated with hotter future climate 
(compare the location of lowest AIL in 2050 between the cool and the hot climate change scenario). In the cool climate perspective, optimum

grazing was able to maintain the highest landscape structural diversity for the near future. In the far future of a hot climate perspective, no true optimum grazing pressure can be identified (the grey solid line is almost horizontal in 2099). Moreover, the AlL value was above 0.7 for all grazing pressures, which indicates a general landscape structural simplification regardless livestock densities.

\subsubsection{Results for climate change scenarios in the presence of shrub-cutting}

The presence of shrub-cutting was generally able to maintain the historic relation between open pastureland and grazing pressure and therefore to mitigate the impact of hotter climate. Our results show that, if the historic optimum grazing (0.5 ABU $\mathrm{ha}^{-1}$ ) is combined with shrub-cutting practices, the pasture is prevented from exceeding $40 \%$ in tree cover even in a far and hotter future (in Fig. 7, the black dotted lines in all diagrams touch zero at 0.5 $\left.\mathrm{ABU} \mathrm{ha}^{-1}\right)$. This would conserve pastureland and prevent the woods to be legally included into forest.

Shrub-cutting also maintained historic landscape structural diversity for low and optimum grazing pressures (compare the grey dotted lines among all diagrams of Fig. 7, with a minimum around the optimum grazing pressure of $0.5 \mathrm{ABU} \mathrm{ha}^{-1}$ ). In the cases of grazing pressure being higher than optimum however, shrub-cutting on the one hand side helped to maintain open pastureland (the area with tree cover more than $40 \%$ was around zero), but landscape structure was simplified (values of AIL increased, grey dotted lines compared to grey solid lines in Fig. 7). This effect is remarkable, because in general the introduction of stochasticity into the model (i.e. random selection of cut-down cells) should disperse the habitat pattern and therefore increase structural diversity, but simulated negative ecological effects from combined cutting and grazing outweighed.

\section{Discussion}

\subsection{Landscape modeling}

The incompatibility between the timeframes of tree development and human life expectancy does not allow for conducting experiments in real-world silvopastoral systems(Pălăghianu 2016; Perry \& Enright 2006). We therefore conducted a landscape modelling study in order to project the potential impacts of climate change on wood-pastures in the Southern Carpathians. We tested land use options for mitigation in a series of hypothetical experiments. Our systematic approach basically followed the analysis of pattern and process relationships along a gradient of grazing pressure. We additionally considered shrub-cutting for being the traditional measure of pasture management. The future variability of grazing pressure and shrub-cutting action was based on the perception of local stakeholders of current and historic land management and the use of subsidies as well as on the existing regulations for pasture management. We expanded the scope of previous studies in wood-pastures of the Southern Carpathians (Peringer et al. 2016 based on historical observations) by the consideration of two climate change scenarios (following Peringer et al. 2013 in the Swiss Jura Mountains) and by the consideration of the traditional multi-use of wood-pastures (combined analysis of grazing and shrub-cutting following Gillet \& Peringer 2012). This framework allowed us to test existing management guidelines for Romanian wood-pastures under future climatic conditions and to propose mitigation measures for climate change impacts.

Regarding the climate change scenarios, the scenario RCP2.6 (van Vuuren et al. 2011) may already be considered implausible regarding temperature levels and extreme events that are major drivers of ecological dynamics, because in recent years the temperatures have already exceeded the projection towards the end of this century (2099 AD). Even in the case of the hot and pessimistic scenario RCP8.5 (Riahi et al. 2011), observed temperatures in 2015 and 2016 at the Fundata weather station have been higher than those projected for 2017-2050. Therefore, simulated changes in landscape structure 
appear to be more likely under the hot climate change scenario than under the cool climate change scenario. Moreover, as climate change scenarios lack recently observed strong fluctuations and extremes, shifts in wood-pasture mosaics can be expected to occur earlier and more abruptly than demonstrated by our simulations, because extremes may trigger qualitative changes in ecological dynamics. Altogether, our suggestions for adapted management may be more urgent than indicated by the simulation's timeframe.

Another simplification in our scenarios is that the simulated grazing and shrub-cutting intensities were held temporally-constant. On the one hand side this is unrealistic. On the other hand side it allowed the clear demonstration of climate change impacts as the unique driver of landscape dynamics in our scenarios. As testing management guidelines in the light of climate change is the innovation of our study, we chose this simple but focused design in order to demonstrate fundamental relationships.

To do so, we highly aggregated the detailed model output (refer to the supplementary material) to the display of key landscape state variables along the gradient in grazing pressure and for the presence or absence of shrub-cutting. The key variables were selected to explain landscape structural diversity and thereby the provision of typical habitats of wood-pastures, i.e. forest-grassland mosaics with interconnecting ecotones (landscape aggregation index AlL following $\mathrm{He}$ et al. 2000).The area where tree cover exceeds the $40 \%$ is based on a legislative threshold that strongly limits future pasture management (refer to the methods section 2.7) and was selected in order to demonstrate the risk of future long-term habitat loss. This approach allowed for a clear illustration of changes in ecological values and in responsibility (delegation between forestand pasture-related authorities) under different management options and future climate change. All conclusions from the diagrams were plausibilitychecked based on the maps of landscape dynamics in the supplementary material.

\subsection{Climate change impacts on the ecology of wood-pastures}

Mountain ecosystems are among the ones where climate change impacts most (Beniston 2005, 2003). In mountain wood-pastures, the following climatic constraints are most importantly altered by climate change and are modelled by WoodPaM: the length of the growing season and the coldness of winters (Peringer et al. 2013). Longer growing seasons basically promote the accumulation of biomass. For the herb layer this means larger amount of forage for livestock. For shrubs and trees this means faster growth and larger amount of seeds (anemochory and zoochory prevail in the reproduction of woody species in the study area). The damage of severe frost events to tree seedlings is reduced.

Altogether, climate change accelerates tree encroachment, because of more frequent and facilitated establishment of seedlings (Peringer \& Rosenthal 2011), their faster growth and reduced browsing damage (Smit et al. 2015; Vandenberghe et al. 2007). The latter is a consequence of the relative decrease of grazing pressure for a given herd size if forage is plenty. Moreover, longer growing seasons allow trees to tolerate more shade and this leads to densification of the canopy with climate warming where in historic times thin mountain forests dominated (Peringer et al. 2015).

Two consequences arise from climate change for the ecological value of wood-pastures in our study and were demonstrated by the model. First, the relative decrease of grazing pressure in combination with facilitated tree and shrub encroachment leads to the maintenance of reduced areas of open pasture by a given herd size, because tree and shrub seedlings that encroach pasture are damaged less and regenerate faster from browsing in prolonged growing seasons. Second, tree canopy densification reduces the forage in former thin canopy forest. In turn, livestock disregards forest for grazing. Forest-grassland mosaic segregation is the consequence and the loss of interconnecting, species-rich ecotones(Peringer et al. 2015). Our simulation results demonstrate both effects that were observed in wood-pastures of the Swiss Jura Mountains and our Romanian study area during the past decades as a combined consequence 
of recent climate warming and land use change (Chetelat et al. 2013; Peringer et al. 2016, 2015)

In order to break this natural trend of mosaic pattern simplification and subsequent loss of habitats, landscape structure requires direct human interference. Here, shrub-cutting is the traditional method that created historic diverse landscape mosaics. However, shrub-cutting may not only focus on encroached pastureland but also on thin canopy forest, where otherwise tree seedlings may readily establish protected by shrubby understory and densify the forest canopy later on. Our modelling of random dispersion of shrub-cutting in the forest-grassland mosaic mimics this approach and demonstrates the beneficial consequences for landscape structural diversity.

\subsection{Guidelines for wood-pasture management}

Many studies made clear that wood-pastures require a degree of human interference that is balanced with natural processes in order to maintain habitat diversity and corresponding biodiversity. Both abandonment and undergrazing, as well as overgrazing and extensive pasture-clearing will lead to the loss of mosaic structures (e.g. Chételat et al. 2013), which are moreover highly sensitive to climatic variability (Peringer et al. 2013). Regarding livestock density and pasture management, guidelines were formulated for the Southern Carpathians based on experience of the past (Romanian Ministry of Agriculture and Rural Development MADR 2013; Maruşca 2014; APIA 2017).

However, currently proposed livestock densities did not show to be sufficient to maintain wood-pasture mosaics and their specific biodiversity without additional shrub-cutting in the future (research question 1). Significant losses of open pastureland and inclusion into forest as well as landscape structural simplification and loss of complex habitats can be expected from climate warming, with more severe consequences in a hotter climate change perspective. This problem is already widespread throughout Romania (Marușca 2014; Sutcliffe et al. 2015a). In the absence of shrub-cutting, only maximum grazing will maintain the open pasture area in the future. Our interviews showed, however, that due to the ongoing exodus from rural areas and stronger economic interest into forest than pasture, this is an unlikely scenario.

Care is needed, however, in the call for more intense pasture management in the future driven by appropriate allocation of subsidies (as requested by the local community of Fundata in our interviews and following the The Farmer's Guide on Ecoconditionality in 2017, issued by the Romanian Ministry of Agriculture and Rural Development MADR, 2017). The effects of combined grazing and shrub-cutting were shown to depend on the grazing pressure. Shrub-cutting may have beneficial effects for low to optimum livestock densities, but may have devastating effects at maximum grazing pressures (question 2). At currently proposed optimum grazing pressure (Maruşca 2014), shrubcutting demonstrated the potential to mitigate climate warming impacts (loss of open pasture and complex habitats through forest encroachment and landscape structural simplification).

\subsubsection{Recommendation of traditional multi-use of wood-pastures}

We recommend the re-establishment of the traditional multi-use of wood-pastures at currently proposed optimum livestock densities (0.5 ABU ha-1, Maruşca 2014) in combination with low-intensity shrub-cutting. Thereby our study demonstrated that traditional practices offer a balanced compromise among agricultural use and habitat mosaics that are robust to climate change. Therefore, we argue to direct subsidies to traditional multi-use rather than to the intensification of grazing pressure by larger herd sizes and necessary infrastructure (watering places and shelter).

Regarding wood-pasture ecology, the benefits of traditional multi-use to counteract climate change impacts are plausible. Shrub-cutting is appropriate to counteract the climate change driven development of dense canopy thickets avoided by livestock, which will therefore segregate from the pasture and turn into forest. Shrub-cutting also offers the opportunity to maintain the optimum livestock density of 0.5 $A B U$ ha-1, which is important for the biodiversity and ecosystem services of the herb layer. The Romanian Guide for Pastoral Management (Marușca et al. 2014) recommends the optimum livestock density in order to maintain a high pastoral value 
for a permanent pasture dominated by Nardus stricta (which is the case for the study area) and to avoid $A B U$ ha-1soil erosion. Low-intensity of shrubcutting is important, because a moderate cover of shrubs serves the prevention of soil erosion in steep mountain terrain (Marușca et al. 2014) and provides important habitats (Gallé et al. 2017; Tölgyesi et al. 2017). Cutting isolated trees should also be avoided because of their high ecological value(Kirby and Watkins, 2015; Hartel et al., 2017a; Roellig et al., 2018).

\subsubsection{Livestock grazing as exclusive management option}

In cases where shrub-cutting is difficult to practice, e.g. in steep and rocky terrain, or when labour lacks in (depopulated) remote regions, a moderate increase of grazing pressure $\left(0.1 \mathrm{ABU} \mathrm{ha}^{-1}\right.$ in our case) in the near future and an increase towards maximum grazing pressure (0.2 $\left.\mathrm{ABU} \mathrm{ha}^{-1}\right)$ in the far future is recommended to maintain pastureland.

The requirement of increasing livestock densities is plausible regarding the increase of forage production by the herb layer with prolonged growing seasons. However, care is needed, because exceeding the optimum grazing pressure might evoke soil erosion and shifts in the biodiversity of the herb layer.

The application of grazing with larger herds as an exclusive management option comes with some further constraints regarding the conservation of landscape structural diversity and pastureland. Without shrub-cutting, the structure of the grassland-forest mosaic is pre-determined by topography and soil (Pătru-Stupariu et al. 2017; Peringer et al. 2017) leading to treeless pasture on deep colluvial productive soils (preferred forage grounds) and woods on unattractive sites for foraging (steep slopes, shallow unproductive soil, Peringer et al. 2017). This livestock-vegetation interaction in complex terrain is causal for the emergence of mosaic patterns in mountain pastures and it becomes more pronounced the stronger the three factors are (i.e. faster vegetation growth, higher grazing pressure and terrain complexity). In our results, the interaction of vegetation and grazing becomes stronger with climate warming due to increased forage production in prolonged growing seasons (on deep soil) and due to facilitated tree regeneration and growth. As a consequence, comparatively rich mosaic patterns emerged in our simulations for warmer climate under all grazing pressures, even under low and maximum grazing pressures. Regardless these results, it should be clear however that only high grazing pressures maintained open pastureland, whereas rich mosaics for low grazing pressures are in fact mosaics of densely wooded habitats subject to forest inclusion. Moreover, such landscape structural diversity is closely coupled to a rich topography, which is the characteristic of mountain pastures. Wood-pastures in plain areas probably show devastating developments in hotter climate, because drought is likely to limit vegetation regeneration and to weaken the livestock-vegetation interaction, and topography pre-determines mosaic patterns to a lesser extent.

\section{Conclusions}

Our work demonstrates that landscape modelling can provide coherent arguments in the sense of mitigation between climate change and the conservation of wood-pasture ecosystem services. Moreover, we establish a functional relationship among pasture management and ecological values as a basis for the conceptualization of subsidies. We underpin the necessity of adapting the current management by taking into account the following aspects.

Firstly, to proceed grazing with current low livestock densities and poor pasture management (absence of shrub-cutting) will threaten large parts of pastureland with tree encroachment and legal inclusion into forest. Future restoration options will then be highly difficult. Such severe consequences are more likely in a (realistic) hotter climate change perspectives within the next decades.

Secondly, the re-establishment of the traditional multi-use of wood-pastures, i.e. currently proposed optimum grazing pressure in combination with lowintensity shrub-cutting, is recommended to maintain the historic landscape structural diversity, key 
habitats for threatened species (open pastureland and grassland-woodland ecotones) and ecosystem services (livestock breeding, prevention from soil erosion). The ecological values appear to be robust even against a hot climate change perspective. We therefore argue to focus future subsidies on traditional management.

Lastly, to stepwise increase herd sizes of livestock up to recommended maximum levels is a tool to maintain pastureland and structural diversity where shrub-cutting is impractical or when subsidies lack. Care is needed however regarding herb layer biodiversity, erosion and topography suitability.

\section{Acknowledgements}

This work was supported by the Swiss Enlargement Contribution in the framework of the RomanianSwiss Research Program, project WindLand, project code: IZERZO_142168/1 and 22 RO-CH/RSRP.

\section{References}

APIA, 2017. Ghid informativ pentru beneficiarii măsurilor de Mediu și Climă ale Programului Național de Dezvoltare Rurală (PNDR) 2014-2020.

Baumann, M.; Kuemmerle, T.; Elbakidze, M.; Ozdogan, M.; Radeloff, V.C.; Keuler, N.S.; Prishchepov, A. V.; Kruhlov, I. \& Hostert, P. 2011. Patterns and drivers of post-socialist farmland abandonment in Western Ukraine. Land use policy 28, 552-562. DOI:10.1016/j.landusepol.2010.11.003

Beaufoy, G.; Jones, G.; De Rijck, K. \& Kazakova, Y. 2008. High Nature Value farmlands: Recognising the importance of South East European landscapesFinal summary report (Bulgaria \& Romania), WWF Danube-Carpathian Programme and EFNCP.

Beniston, M. 2005. The Risks Associated with Climatic Change in Mountain Regions, in: Huber, U.M.; Bugmann, H.K.M.; Reasoner, M.A. (Eds.), Global
Change and Mountain Regions: An Overview of Current Knowledge. Springer Netherlands, Dordrecht, pp. 511-519. DOI:10.1007/1-40203508-X_51

Beniston, M. 2003. Climatic Change in Mountain Regions: A Review of Possible Impacts. Climatic Change 59, 5-31. DOI:10.1023/A:1024458411589

Bergmeier, E.; Petermann, J. \& Schröder, E. 2010. Geobotanical survey of wood-pasture habitats in Europe: Diversity, threats and conservation. Biodiversity Conservation 19, 2995-3014. DOI:10.1007/s10531-010-9872-3

Bîrsan, M.-V. \& Dumitrescu, A. 2014. ROCADA: Romanian daily gridded climatic dataset (19612013) V1.0. DOI:10.1594/PANGAEA.833627

Bojariu, R.; Bîrsan, M.-V.; Cică, R.; Velea, L.; Burcea, S.; Dumitrescu, A.; Dascălu, S.I.; Gothard, M.; Dobrinescu, A.; Cărbunaru, F. \& Lenuța, M. 2015. Schimbările climatice - de la bazele fizice la riscuri şi adaptare. EDITURA PRINTECH, Bucharest.

Brandt, J. 2003. Multifunctional landscapes - Perspectives for the future. Journal of Environmental Sciences (China) 15, 187-192.

Buttler, A.; Gavazov, K.; Peringer, A.; Siehoff, S.; Mariotte, P.; Wettstein, J.B.; Chételat, J.; Huber, R.; Gillet, F. \& Spiegelberger, T. 2012. Erhaltung der Wytweiden im Jura: Klimatische und agrarpolitische Herausforderungen. Agrarforschung Schweiz 3, 346-353.

Chetelat, J.; Kalbermatten, M.; Lannas, K.S.M.; Spiegelberger, T.; Wettstein, J.B.; Gillet, F.; Peringer, A. \& Buttler, A. 2013. A contextual analysis of land-use and vegetation changes in two wooded pastures in the Swiss Jura Mountains. Ecology and Society 18. DOI:10.5751/ES-05287-180139

Danell, K.; Bergström, R.; Duncan, P. \& Pastor, J. 2006. Large Herbivore Ecology, Ecosystem Dynamics and Conservation, Conservation Biology. Cambridge University Press. DOI:10.1017/ CBO9780511617461 
Doniță, N.; Biriș, I.; Popescu, A.; Pauca-Comanescu, M. \& Mihailescu, S. 2005. Habitatele din România.

Dorresteijn, I.; Hartel, T.; Hanspach, J.; von Wehrden, H. \& Fischer, J. 2013. The Conservation Value of Traditional Rural Landscapes: The Case of Woodpeckers in Transylvania, Romania. PLoS One 8. DOI:10.1371/journal.pone.0065236

Dovčiak, M.; Hrivnák, R.; Ujházy, K. \& Gömöry, D. 2007. Seed rain and environmental controls on invasion of Picea abies into grassland. Plant Ecology 194, 135-148. DOI:10.1007/s11258-0079280-2

Farina, A. 2006. Principles and methods in landscape ecology: toward a science of landscape. Springer, London.

Flynn, J.P. 1973. Snowball Sampling for Voluntary Participation Research. Journal of Voluntary Action Research 2, 60-63. DOI:10.1177/089976407300200106

Fontana, V.; Radtke, A.; Walde, J.; Tasser, E.; Wilhalm, T.; Zerbe, S. \& Tappeiner, U. 2014. What plant traits tell us. Consequences of land-use change of a traditional agro-forest system on biodiversity and ecosystem service provision. Agriculture, Ecosystems \& Environment, Vol. 186, 44-53.

Gallandat, J.-D.; Gillet, F.; Havlickec, E. \& Perrenoud, A. 1995. Typologie et systémique phyto-écologiques des, PATUBOIS.

Gavazov, K.; Peringer, A.; Buttler, A.; Gillet, F. \& Spiegelberger, T. 2013. Dynamics of forage production in pasture-woodlands of the Swiss Jura Mountains under projected climate change scenarios. Ecology 18, 13. DOI:10.5751/ES-04974180138

Gillet, F. 2008. Modelling vegetation dynamics in heterogeneous pasture-woodland landscapes. Ecological Modelling 217, 1-18. DOI:10.1016/j. ecolmodel.2008.05.013
Gillet, F. \& Peringer, A. 2012. Dynamic modelling of silvopastoral landscape structure: Scenarios for future climate and land use. iEMSs 2012 - Managing Resources of a Limited Planet: Proceedings of the 6th Biennial Meeting of the International Environmental Modelling and Software Society, 860-867.

Gordon, I.J. \& Prins, H.H.T. 2008. The Ecology of Browsing and Grazing, Ecological Studies. Springer Berlin Heidelberg, Berlin, Heidelberg. DOI:10.1007/978-3-540-72422-3

Government of Romania, 2013. Emergency Ordinance no. 34/2013- OUG nr. 34/2013 privind organizarea, administrarea si exploatarea pajistilor permanente si pentru modificarea si completarea Legii fondului funciar nr. 18/1991.

Hartel, T.; Dorresteijn, I.; Klein, C.; Máthé, O.; Moga, C.I.; Öllerer, K.; Roellig, M.; von Wehrden, H. \& Fischer, J. 2013. Wood-pastures in a traditional rural region of Eastern Europe: Characteristics, management and status. Biological Conservation 166, 267-275. doi:10.1016/j.biocon.2013.06.020

Hartel, T.; Hanspach, J.; Abson, D.J.; Máthé, O.; Moga, C.I. \& Fischer, J. 2014. Bird communities in traditional wood-pastures with changing management in Eastern Europe. Basic and Applied Ecology 15, 385-395. DOI:10.1016/j. baae.2014.06.007

Hartel, T.; Hanspach, J.; Moga, C.I.; Holban, L.; Szapanyos, Á.; Tamás, R.; Hováth, C. \& Réti, K.O., 2018. Abundance of large old trees in woodpastures of Transylvania (Romania). Science of the Total Environment, 613-614, 263-270. DOI:10.1016/j.scitotenv.2017.09.048

Hartel, T. \& Plieninger, T. 2014. European woodpastures in transition: a social-ecological approach, Routledge Edition, Agroforestry Systems. DOI:10.1007/s10457-014-9779-1 
Hartel, T.; Plieninger, T. \& Varga, A. 2015. Woodpastures in Europe. Europe's changing woods and forests: from wildwood to managed landscapes 61-76. DOI:10.1079/9781780643373.0061

Hartel, T.; Réti, K.O. \& Craioveanu, C. 2017. Valuing scattered trees from wood-pastures by farmers in a traditional rural region of Eastern Europe. Agriculture, Ecosystems and Environment 236, 304-311. DOI:10.1016/j.agee.2016.11.019

Huber, R.; Briner, S.; Peringer, A.; Lauber, S.; Seidl, R.; Widmer, A.; Gillet, F.; Buttler, A.; Le, Q.B. \& Hirschi, C. 2013a. Modeling Social-Ecological Feedback Effects in the Implementation of Payments for Environmental Services in Pasture-Woodlands. Ecology and Society 18, art41. DOI:10.5751/ES05487-180241

Huber, R.; Rigling, A.; Bebi, P.; Brand, F.S.; Briner, S.; Buttler, A.; Elkin, C.; Gillet, F.; Grêt-Regamey, A.; Hirschi, C.; Lischke, H.; Scholz, R.W.; Seidl, R.; Spiegelberger, T.; Walz, A.; Zimmermann, W. \& Bugmann, H. 2013b. Sustainable land use in mountain regions under global change: Synthesis across scales and disciplines. Ecology and Society 18. DOI:10.5751/ES-05499-180336

Hilpold, A.; Seeber, J.; Fontana, V.; Niedrist, G.; Rief, A.; Steinwandter, M.; Tasser, E. \& Tappeiner, U. 2018. Decline of rare and specialist species across multiple taxonomic groups after grassland intensification and abandonment. Biodiversity and Conservation, Vol. 27, 3729-3744.

Jacob, D.; Petersen, J.; Eggert, B.; Alias, A.; Christensen, O.B.; Bouwer, L.M.; Braun, A.; Colette, A.; Déqué, M.; Georgievski, G.; Georgopoulou, E.; Gobiet, A.; Menut, L.; Nikulin, G.; Haensler, A.; Hempelmann, N.; Jones, C.; Keuler, K.; Kovats, S.; Kröner, N.; Kotlarski, S.; Kriegsmann, A.; Martin, E.; van Meijgaard, E.; Moseley, C.; Pfeifer, S.; Preuschmann, S.; Radermacher, C.; Radtke, K.; Rechid, D.; Rounsevell, M.; Samuelsson, P.; Somot, S.; Soussana, J.F.; Teichmann, C.; Valentini, R.; Vautard, R.; Weber, B. \& Yiou, P. 2014. EUROCORDEX: New high-resolution climate change projections for European impact research.
Regional Environmental Change 14, 563-578. DOI:10.1007/s10113-013-0499-2

Kirby, K.J. \& Watkins, C. 2015. Europe's changing woods and forests: From wildwood to managed landscapes. CABI Publishing, Wallingford, Oxfordshire, UK. DOI 10.1079/9781780643373.0000

Kuemmerle, T.; Müller, D.; Griffiths, P. \& Rusu, M. 2009. Land use change in Southern Romania after the collapse of socialism. Regional Environmental Change 9, 1-12. DOI:10.1007/s10113-008-0050-z

Loos, J.; Dorresteijn, I.; Hartel, T.; Abson, D.J.; Hanspach, J.; Horcea-Milcu, I.A.; Mikulcak, F. \& Fischer, J. 2016. Sustainable Landscapes in Central Romania: A social-ecological study on the future of Southern Transylvania. Pensoft.

MADR 2017. Ghidul fermierului privind ecocondiționalitatea în anul 2017. Official document emitted by the Ministry of Agriculture and Sustainable Development, Romania.

MADR 2013. Ordinul nr. 544/2013 privind metodologia de calcul al încărcăturii optime de animale pe hectar de pajiște. Official document emitted by the Ministry of Agriculture and Sustainable Development, Romania.

Makarewicz, K.; Schwaiger, E. \& Brodsky, L. 2012. Updated High Nature Value Farmland in Europe 0-61, European Environment Agency.

Marușca, T. 2014. Pajiștea, cel mai complex ecosistem sărăcit de ignoranță. Revista Lumea Satului, nr. 21 (218), 1-15 noiembrie 2014.

Marușca, T.; Vasile, M. \& Haș, E. 2014. Ghid de întocmire a amenajamentelor pastorale. Editura Capolavoro, Brașov, Romania. 
Moberg, A.; Sonechkin, D.M.; Holmgren, K.; Datsenko, N.M.; Karlén, W. \& Lauritzen, S.-E. 2005. Highly variable Northern Hemisphere temperatures reconstructed from low- and highresolution proxy data. Nature 433, 613-617. DOI:10.1038/nature03298.1.

Munteanu, C.; Kuemmerle, T.; Boltiziar, M.; Butsic, V.; Gimmi, U.; Lúboš Halada, Kaim, D.; Király, G.; Konkoly-Gyuró, É.; Kozak, J.; Lieskovský, J.; Mojses, M.; Müller, D.; Ostafin, K.; Ostapowicz, K.; Shandra, O.; Štych, P.; Walker, S. \& Radeloff, V.C. 2014. Forest and agricultural land change in the Carpathian region-A meta-analysis of long-term patterns and drivers of change. Land use policy 38, 685-697. DOI:10.1016/j.landusepol.2014.01.012

Olff, H. \& Ritchie, M. 1998. Effects of herbivores on grassland diversity. Trends in Ecology \& Evolution. DOI:10.1016/S0169-5347(98)01364-0

Olff, H.; W. M. Vera, F.; Bokdam, J.; Bakker, E.; Gleichman, J.M.; D. de Maeyer, K. \& Smit, R. 1999. Shifting Mosaics in Grazed Woodlands Driven by the Alternation of Plant Facilitation and Competition. Plant Biology. DOI:10.1111/j.1438-8677.1999.tb00236.x

Öllerer, K. 2013. On the Spatio-Temporal Approaches Towards Conservation of Extensively Managed Rural Landscapes in Central-Eastern Europe. J. Landscape Ecology 6. DOI:10.2478/v10285-0120062-8

Pălăghianu, C. 2016. Analiza regenerarii padurii: perspective statistice si informatice. DOI:10.13140/RG.2.1.5114.1203

Palang, H.; Printsmann, A.; Gyuró, É.K.; Urbanc, M.; Skowronek, E. \& Woloszyn, W. 2006. The forgotten rural landscapes of Central and Eastern Europe. Landscape Ecology 21, 347-357. DOI:10.1007/ s10980-004-4313-x
Parlamentul României 2017. Legea nr. 175/2017 pentru modificarea și completarea Legii nr. 46/2008 - Codul silvic, precum și pentru modificarea art. 5 alin. (2) din Legea nr. 192/2010.

Parlamentul României 2008. Codul Silvic- Legea 46/2008 (Romanian Forest Code).

Patru-Stupariu, I. 2011. Peisaj si gestiunea durabila a teritoriului. Aplicatii la culoarul transcarpatic Bran-Rucar-Dragoslavele.

Pătru-Stupariu, I.; Stupariu, M.-S.; Cuculici, R. \& Huzui, A. 2011. Understanding landscape change using historical maps. Case study Sinaia, Romania. J. Maps 7, 206-220. DOI:10.4113/jom.2011.1151

Pătru-Stupariu, I.; Stupariu, M.S.; Stoicescu, I.; Peringer, A.; Buttler, A. \& Fürst, C. 2017. Integrating geo-biodiversity features in the analysis of landscape patterns. Ecological Indicators 80, 363-375. DOI:10.1016/j.ecolind.2017.05.010

Pepene, N. \& Popovici, B.F. 2012. Comuna Fundata, o istorie in imagini. Comuna Primariei Fundata.

Peringer, A.; Buttler, A.; Gillet, F.; Stupariu, I.; Schulze, K.; Stupariu, M.S. \& Rosenthal, G. 2017. Disturbance-grazer-vegetation interactions maintain habitat diversity in mountain pasturewoodlands. Ecological Modelling. DOI:10.1016/j. ecolmodel.2017.06.012

Peringer, A.; Gillet, F.; Rosenthal, G.; Stoicescu, I.; Pătru-Stupariu, I.; Stupariu, M.-S. \& Buttler, A. 2016. Landscape-scale simulation experiments test Romanian and Swiss management guidelines for mountain pasture-woodland habitat diversity. Ecological Modelling 330, 41-49. DOI:10.1016/j. ecolmodel.2016.03.013

Peringer, A. \& Rosenthal, G. 2011. Establishment patterns in a secondary tree line ecotone. Ecological Modelling - ECOL Model 222, 31203131. DOI:10.1016/j.ecolmodel.2011.05.025 
Peringer, A.; Schulze, K.A.; Stupariu, I.; Stupariu, M.S.; Rosenthal, G.; Buttler, A. \& Gillet, F. 2015. Multiscale feedbacks between tree regeneration traits and herbivore behavior explain the structure of pasture-woodland mosaics. Landscape Ecology 31, 913-927. DOI:10.1007/s10980-015-0308-z

Peringer, A.; Siehoff, S.; Chételat, J.; Spiegelberger, T.; Buttler, A. \& Gillet, F. 2013. Past and future landscape dynamics in pasture-woodlands of the Swiss Jura Mountains under climate change. Ecology and Society 18 (3): 11. DOI:10.5751/ES05600-180311

Perry, G. L. W. \& Enright, N. J. 2006. Spatial modelling of vegetation change in dynamic landscapes: a review of methods and applications. Progress in Physical Geography: Earth and Environment 30, 47-72. DOI:10.1191/0309133306pp469ra

Plieninger, T.; Hartel, T.; Martín-López, B.; Beaufoy, G.; Bergmeier, E.; Kirby, K.; Montero, M.J.; Moreno, G.; Oteros-Rozas, E. \& Van Uytvanck, J. 2015. Wood-pastures of Europe: Geographic coverage, social-ecological values, conservation management, and policy implications. Biology and Conservation 190, 70-79. DOI:10.1016/j. biocon.2015.05.014

Plieninger, T.; Pulido, F. J. \& Konold, W. 2003. Effects of land-use history on size structure of holm oak stands in Spanish dehesas: implications for conservation and restoration. Environmental Conservation 30, 61-70. DOI:10.1017/ S0376892903000055

Riahi, K.; Rao, S.; Krey, V.; Cho, C.; Chirkov, V.; Fischer, G.; Kindermann, G.; Nakicenovic, N. \& Rafaj, P.,2011. RCP 8.5-A scenario of comparatively high greenhouse gas emissions. Climatic Change 109, 33-57. DOI:10.1007/s10584-011-0149-y

Roellig, M.; Costa, A.; Garbarino, M.; Hanspach, J.; Hartel, T.; Jakobsson, S.; Lindborg, R.; Mayr, S.; Plieninger, T.; Sammul, M.; Varga, A. \& Fischer, J. 2018. Post Hoc Assessment of Stand Structure Across European Wood-Pastures: Implications for Land Use Policy. Rangeland Ecology and Management 72 (5),526-535. DOI:10.1016/j. rama.2018.04.004
Roellig, M.; Dorresteijn, I.; Wehrden, H. Von; Hartel, T. \& Fischer, J. 2014. Brown bear activity in traditional wood-pastures in Southern Transylvania, Romania Brown bear activity in traditional wood-pastures in Southern. Ursus 25, 43-52. DOI:10.2192/URSUS-D-13-00007.1

Smit, C.; Béguin, D.; Buttler, A. \& Müller-Schärer, H. 2005. Safe sites for tree regeneration in wooded pastures: A case of associational resistance? Journal of Vegetation Science 16, 209-214. DOI:10.1111/j.1654-1103.2005.tb02357.x

Smit, C.; L. Ruifrok, J.; van Klink, R. \& Olff, H. 2015. Rewilding with large herbivores: The importance of grazing refuges for sapling establishment and wood-pasture formation. Biology and Conservation 182, 134-142 DOI:10.1016/j. biocon.2014.11.047

Sutcliffe, L.; Akeroyd, J.; Page, N. \& Popa, R. 2015a. Combining Approaches to Support High Nature Value Farmland in Southern Transylvania, Romania. Hacquetia 14, 53-63. DOI:10.1515/ hacq-2015-0011

Sutcliffe, L.; Batáry, P.; Kormann, U.; Báldi, A.; Dicks, L. V.; Herzon, I.; Kleijn, D.; Tryjanowski, P.; Apostolova, I.; Arlettaz, R.; Aunins, A.; Aviron, S.; Baležentienè, L.; Fischer, C.; Halada, L.; Hartel, T.; Helm, A.; Hristov, I.; Jelaska, S.D.; Kaligarič, M.; Kamp, J.; Klimek, S.; Koorberg, P.; Kostiuková, J.; Kovács-Hostyánszki, A.; Kuemmerle, T.; Leuschner, C.; Lindborg, R.; Loos, J.; Maccherini, S.; Marja, R.; Máthé, O.; Paulini, I.; Proença, V.; Rey-Benayas, J.; Sans, F. X.; Seifert, C.; Stalenga, J.; Timaeus, J.; Török, P.; van Swaay, C.; Viik, E. \& Tscharntke, T. 2015b. Harnessing the biodiversity value of Central and Eastern European farmland. Diversity and Distributions 21, 722-730. DOI:10.1111/ ddi.12288

Sutcliffe, L.; Paulini, I.; Jones, G.; Marggraf, R. \& Page, N. 2013. Pastoral commons use in Romania and the role of the Common Agricultural Policy. International Journal of the Commons 7, 58-72. DOI:10.18352/ijc.367 
Tucker, G. \& Beaufoy, G. 2014. Common Framework for Biodiversity-Proofing of the EU Budget General guidance. Report to the European Commission, Institute for European Environmental Policy, London.

van Vuuren, D.P.; Stehfest, E.; den Elzen, M. G.J.; Kram, T.; van Vliet, J.; Deetman, S.; Isaac, M.; Goldewijk, K. K.; Hof, A.; Beltran, A. M.; Oostenrijk, R. \& van Ruijven, B. 2011. RCP2.6: Exploring the possibility to keep global mean temperature increase below $2^{\circ} \mathrm{C}$. Climatic Change 109, 95-116. DOI:10.1007/ s10584-011-0152-3

Vandenberghe, C.; Freléchoux, F.; Moravie, M.-A.; Gadallah, F. \& Buttler, A. 2007. Short-Term Effects of Cattle Browsing on Tree Sapling Growth in Mountain Wooded Pastures. Plant Ecology 188, 253-264. DOI:10.1007/s11258-006-9160-1

Vera, F. W. M. 2000. Grazing ecology and forest history. CABI Publishing, Wallingford, Oxfordshire, UK. 
Appendix 1: Comparison of 1977 and 2013 aerial images of the study area. Sources: US Geological Survey (1977) and WindLand research project (2013 image); Time frame: 36 years - covering one generation of spruce. A: Pasture on easily accessible terrain, close to settlements: no encroachment even after the 25-year post-communism period, due to ongoing intensive land use. B: Maintenance of a wood-pasture mosaic; includes the simulation area selected for this paper. C: Visible effects of land use change on two sides of a fence: forest encroachment to the West, of lower intensity to the East (trees even encroach inside the fenced area). This shows that a period of 30 years is sufficient for a dramatic loss of open pasture to spruce thickets. Moreover, it shows that encroachment may extend up to a distance of 150 meters, which confirms the analysis of Dovčiak et al. 2007. D: Forest densification in the proximity of commonage pastures (part of Argeș county). E: Visible logging area
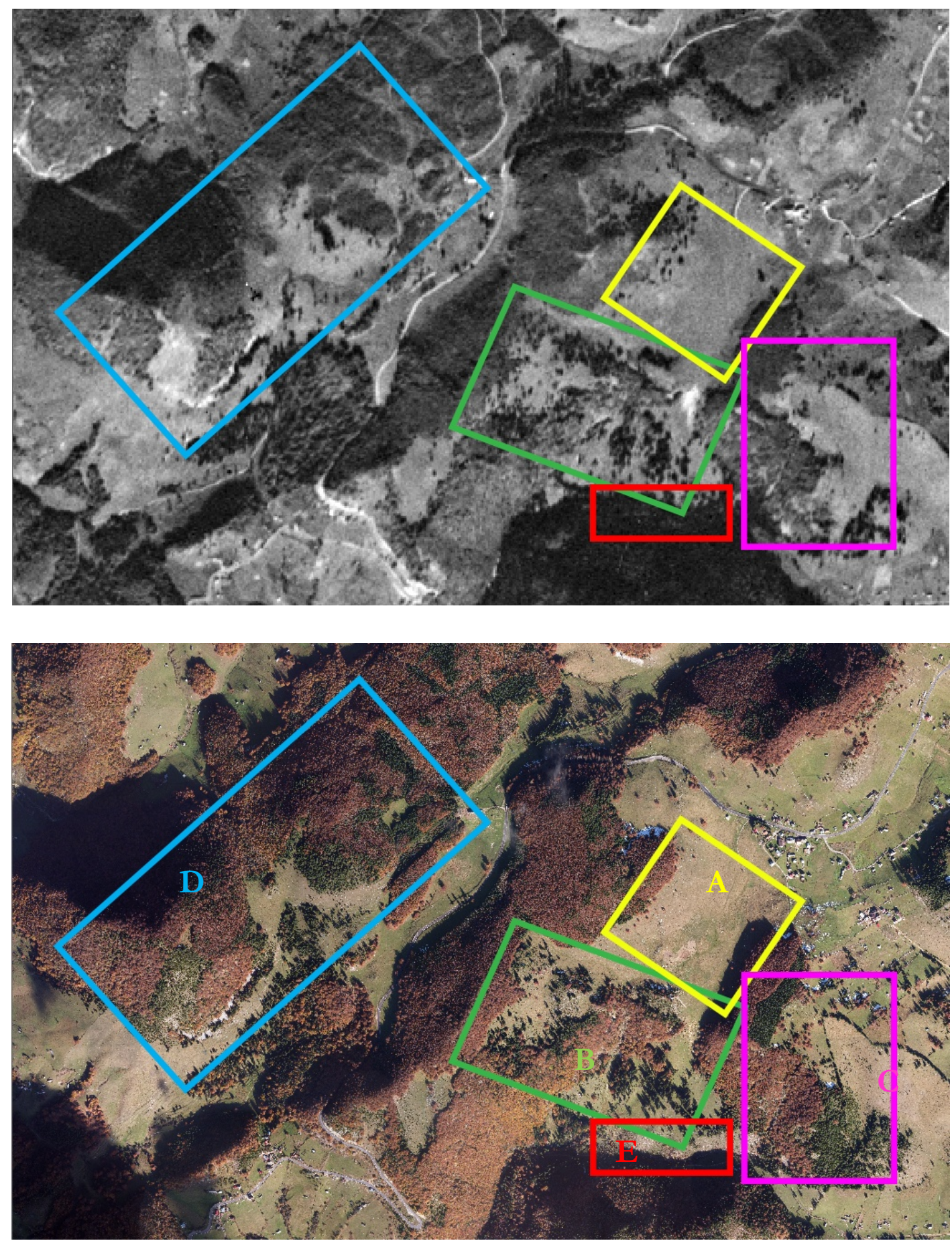
1Appendix 2: Topography input data-ArcGIS display

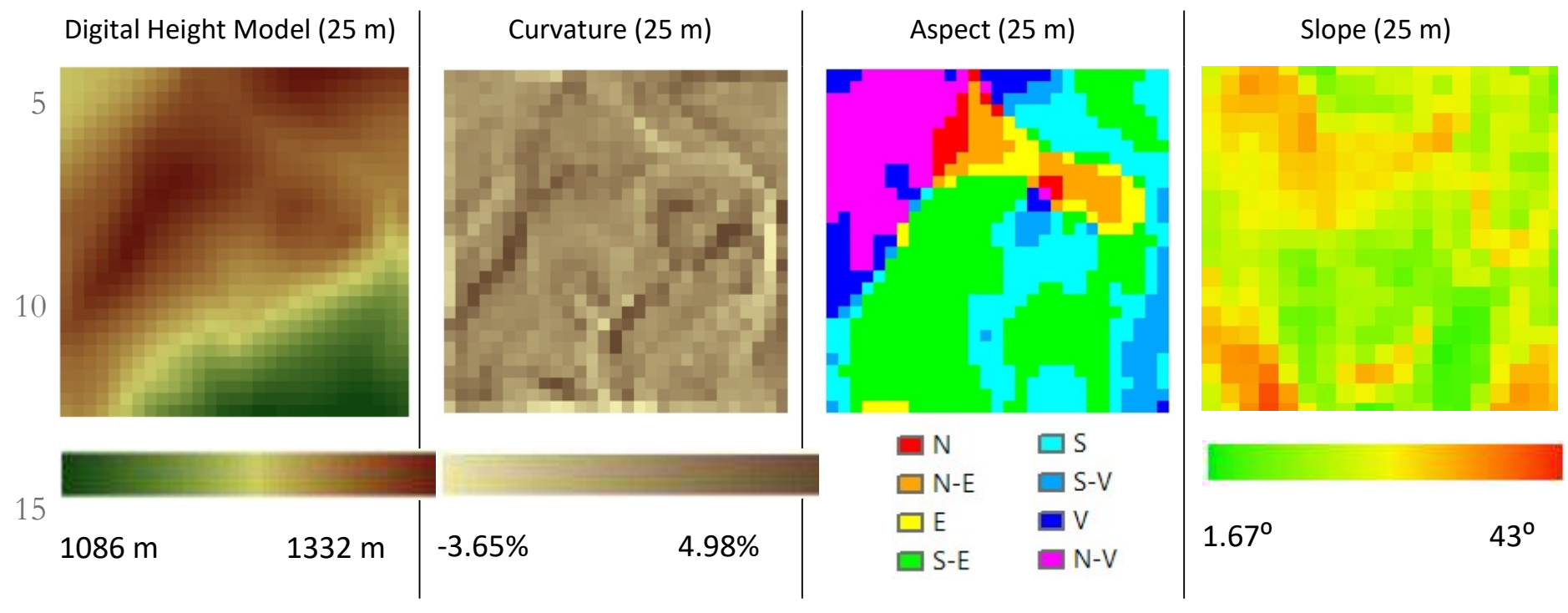

Appendix 3: The spatial representation of the simulated landscape in WoodPaM

25

Altitude

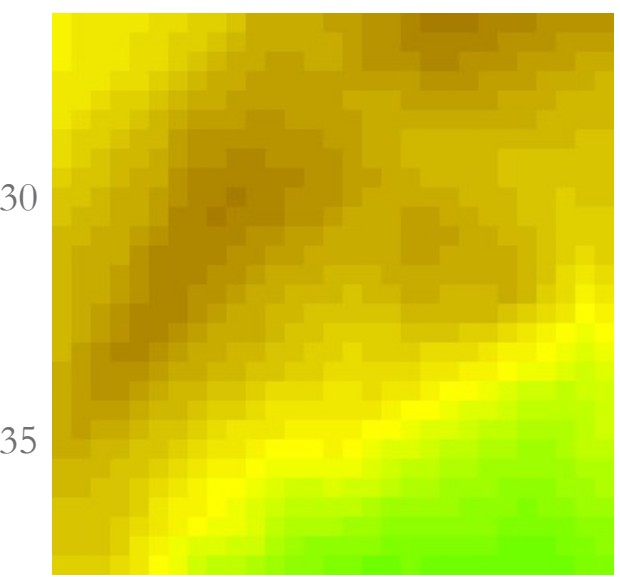

40

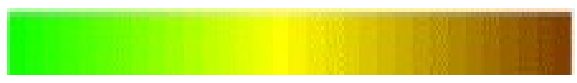

$1000 m$

$1400 m$
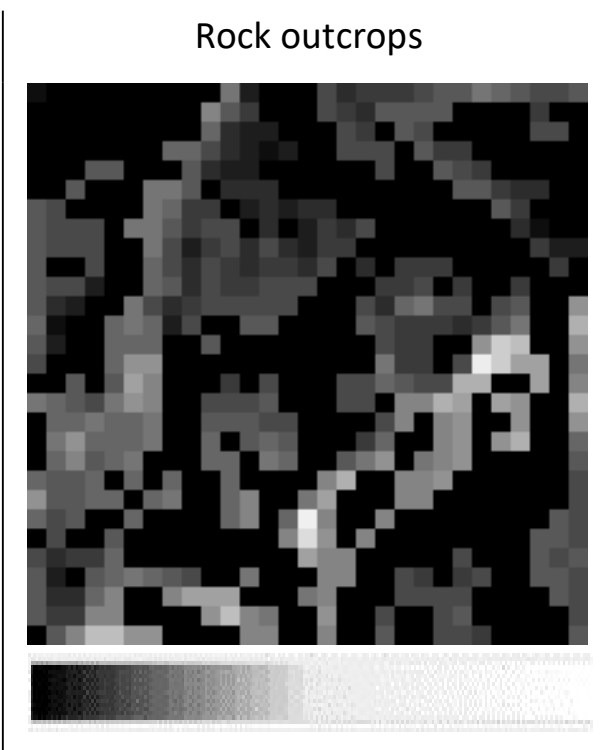

$0 \%$

$50 \%$

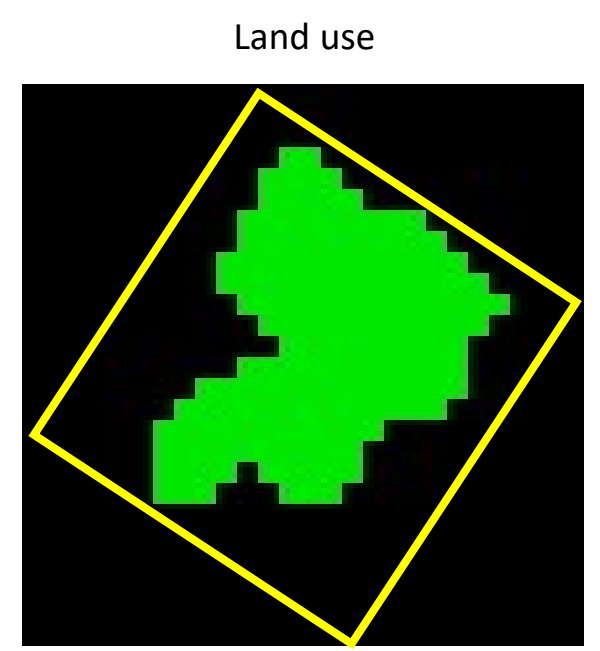

Simulated wood-pasture

Closed forest 
Appendix 4: Development of the spatial distribution of habitat types (see Appendix 5 for habitat definitions) along all scenarios (see Tab. 2) at the three analytical time steps. Maps of simulated habitat types for all scenarios, in the three analytical time steps (2013, 2050 and 2099).

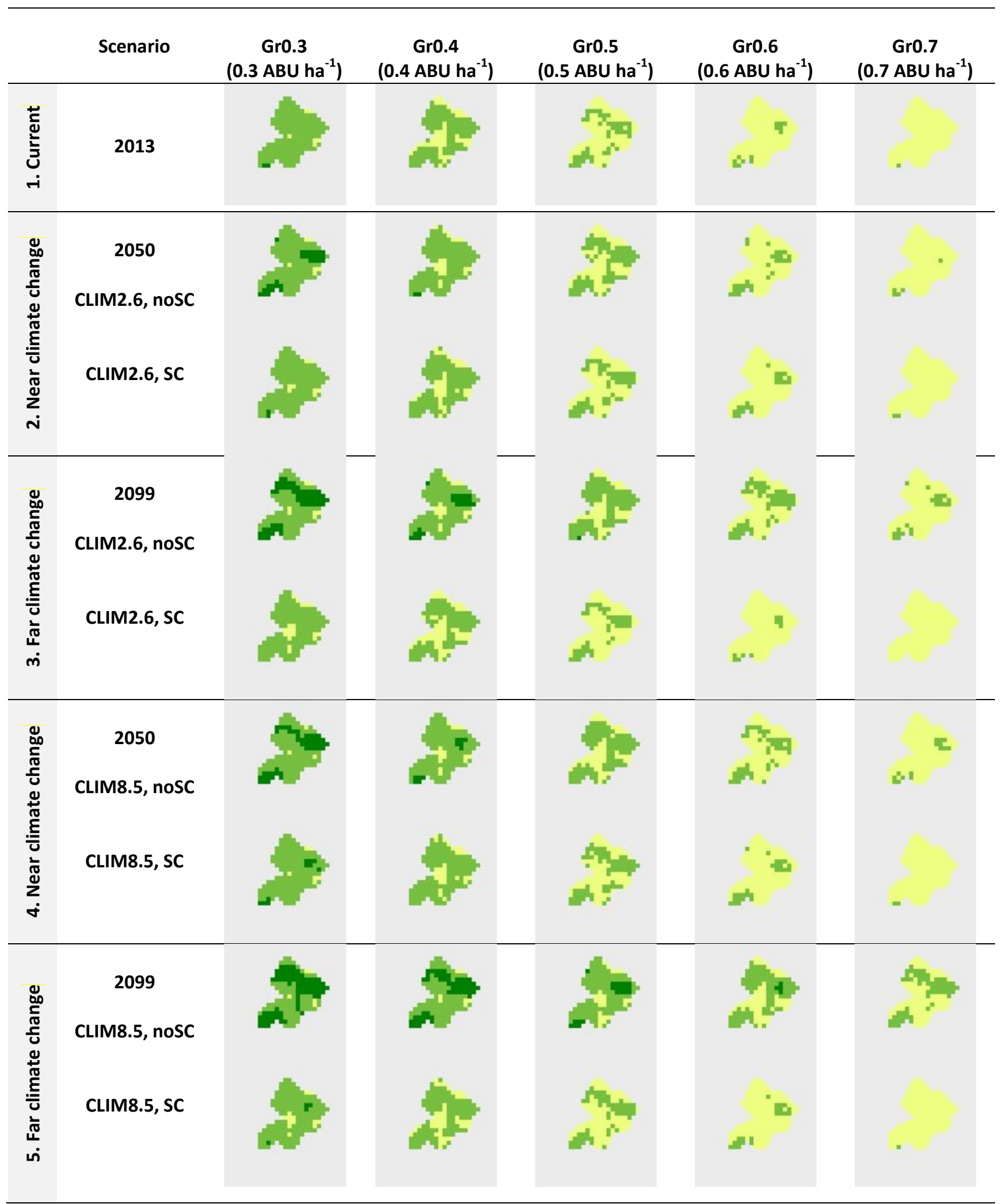

$1 / 2 / 3 / 4$ 
Appendix 5: Legend and structural definition of habitat types based on phytosociological analysis(Gallandat et al. 1995)

\begin{tabular}{cl}
\hline Code & Definition of phytocoenosis type \\
\hline 1 & Unwooded pasture with tree cover below $1 \%$. \\
\hline 2 & $\begin{array}{l}\text { Sparsely wooded pasture with tree cover ranging between } 1 \% \text { and } 20 \% \text {, trees or bushes } \\
\text { being mostly scattered. }\end{array}$ \\
\hline 3 & $\begin{array}{l}\text { Densely wooded pasture with tree cover ranging between } 20 \% \text { and } 70 \% \text {, with trees } \\
\text { clustered in thickets. }\end{array}$ \\
\hline 4 & Grazed forest with tree cover higher than $70 \%$, appearing as forest with a closed canopy. \\
\hline
\end{tabular}

When analysing scenario Gr0.3 (0.3 ABU ha-1), the corresponding maps clearly illustrate forest encroachment (the lack of true open pasture) under all climate and shrub-cutting scenarios. The maximum livestock density ( $\left.0.7 \mathrm{ABU}^{\mathrm{ha}} \mathrm{w}^{-1}\right)$ led to an almost treeless pasture. The optimum grazing scenario Gr0.5 (0.5 ABU ha- $\left.{ }^{-1}\right)$ maintained habitat mosaics when combined with shrub-cutting, but led to forest encroachment when pasture cleaning lacked and climate warming was intense. An increased grazing pressure of $0.6 \mathrm{ABU}$ ha $^{-1}$ maintained open pastureland under near and future climate change.

On a horizontal analysis, the maps corresponding to hot climate show that pasture management relying solely on grazing threaten large parts of pastureland with tree encroachment.

Appendix 6: In red: landscape areas for which the simulated tree cover exceeds $40 \%$ of the cell and which therefore might become included into forest and segregated from pastureland.

\begin{tabular}{|c|c|c|c|c|c|c|}
\hline & Scenario & $\begin{array}{c}\text { Gr0.3 } \\
(0.3 \text { UVM/ha) }\end{array}$ & $\begin{array}{c}\text { Gro.4 } \\
(0.4 \mathrm{UVM} / \mathrm{ha})\end{array}$ & $\begin{array}{c}\text { Gro.5 } \\
(0.5 \text { UVM/ha) }\end{array}$ & $\begin{array}{c}\text { Gro.6 } \\
\text { (0.6 UVM/ha) }\end{array}$ & $\begin{array}{c}\text { Gro.7 } \\
(0.7 \text { UVM/ha) }\end{array}$ \\
\hline $\begin{array}{l}\text { 苞 } \\
\text { 产 }\end{array}$ & 2013 & & $=$ & & & \\
\hline & 2050 & & & I & & \\
\hline $\begin{array}{l}\text { 章 } \\
\frac{10}{2}\end{array}$ & CLIM2.6, SC & & $\square$ & & & \\
\hline 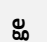 & 2099 & & & & 1 & \\
\hline 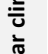 & CLIM2.6, SC & & & & & \\
\hline 茄 & 2050 & & & E & & \\
\hline 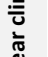 & CLIM8.5, SC & & & & & \\
\hline 觉 & 2099 & & & & & \\
\hline 站 & CLIM8.5, SC & & & & & \\
\hline & & & $=1$ & & & \\
\hline
\end{tabular}

